\title{
JAK VYSOKÉ JE KORPORÁTNÍ DAŇOVÉ ZATÍŽENÍ?
}

\section{Irena Szarowská}

\section{Klíčová slova:}

korporátní důchodová daň, statutární a efektivní daňové zatížení, průměrná daňová sazba, efektivní marginální daňová sazba EMTR, průměrné efektivní daňová sazba EATR, daňová konkurence

\section{Keywords:}

corporate income tax, statutory and effective tax burden, average tax rate, effective marginal tax rate, effective average tax rate, tax competition

\begin{abstract}
Abstrakt
Článek je zaměřen na korporátní daňové zatížení. Jeho cílem je zjistit, na základě jakých sazeb je možné porovnávat korporátní daňové zatížení, jelikož pro komparaci výše korporátního daňového zatížení je možné použít několik metod a sazeb. Statutární sazby nejsou vhodnými ukazateli pro porovnávání skutečného korporátního daňového zatížení, a proto se pro tyto účely častěji využívají efektivní korporátní sazby daně. V případě efektivních sazeb lze nalézt tři základní metody jejich určení, a to metody zpětného makropohledu, zpětného mikropohledu a dopředného mikropohledu. Rozdíly mezi jednotlivými přístupy jsou dány rozdíly $\mathrm{v}$ používaných datech a různém stupni agregace dat. Při rozhodování o alokaci aktiv se používají zejména průměrné daňové sazby, efektivní marginální daňové sazby EMTR nebo průměrné efektivní daňové sazby EATR, které se pro svou komplexnost jeví jako nejpřesnější pro porovnávání korporátního daňového zatížení.
\end{abstract}

\begin{abstract}
The acticle is focused on corporate income tax. The aim of the article is to determine tax rates for comparing corporate tax burden as several methods and rates can be used for comparison of corporate tax burden. Statutory corporate income tax rates are not the right indicator for the comparison of the real economic tax burden so effective corporate tax rate are often used for these purpose. Effective corporate income tax rates can be based on three different methods: macro backward looking, micro backward looking or micro forward looking. Differences between the approaches are used due to differences in data and varying degrees of data aggregation. Following tax rates are mostly used for decisions about asset allocation: average tax rate, effective marginal tax rate EMTR or average effective tax rate EATR. EATR seems to be the most accurate rate for compaing the corporate tax burden due to its complexity.
\end{abstract}

\section{Úvod}

S pokračující globalizací se kapitál stává stále mobilnějším mezi zeměmi. Daňový systém a výše korporátního daňového zatížení trvale zůstává jedním z rozhodujících faktorů při rozhodování podnikového managementu o alokaci investic. Členské státy Evropské unie (EU) mají v zásadě samostatné daňové systémy a uplatňují samostatné daňové politiky. Uspořádání těchto systémů vychází z rozdílných ekonomických, sociologických, historických a dalších faktorů. Evropský hospodářský a sociální výbor (2006) zmiňuje, že OECD v roce 1990 uvedla, že 60 \% světového obchodu probíhá v rámci obchodních skupin. Existence

\footnotetext{
${ }^{1}$ Tento článek vznikl za podpory grantu - GAČR 402/08/0067 - Finanční integrace nových členských zemí EU s eurozónou.
} 
rozdílných daňových systémů, a $\mathrm{v}$ případě daně $\mathrm{z}$ příjmů právnických osob rozdílů v systémech zdanění společností, vytváří překážky přeshraniční činnosti těchto společností a má za následek administrativní a ekonomickou neefektivnost a negativní dopad na hospodářský růst a konkurenceschopnost podniků jak na vnitřním, tak i na mezinárodním trhu. Daňové prostředí, ve kterém se firma pohybuje, působí na výši a rozdělování disponibilního zisku, výběr optimální finanční a majetkové struktury, investování apod., což př́mo souvisí s finančním postavením firmy, jeho jednotlivými činnostmi a působí i na výrobní faktory. Pro zahraniční investory je tedy výše zdanění jedním z důležitých hledisek pro volbu místa podnikání, důležitým kritériem je rovněž administrativní složitost daní a jejich celkový počet $\mathrm{v}$ jednotlivých zemích. Obecně investoři volí při alokaci zemi s nízkým daňovým zatížením a nízkými mzdovými náklady na pracovní sílu.

Korporátní daňové zatížení je významným faktorem při rozhodování investorů o alokaci aktiv. Otázkou však je, na základě jakých metod a sazeb korporátní daňové zatížení hodnotit. Cílem článku je představit přístupy $\mathrm{k}$ měření korporátního zdanění, poukázat na rozdíly mezi nimi a zjistit, který druh korporátní sazby daně se používá při rozhodování o alokaci investic v empirických studiích.

\section{Teoretická východiska korporátních daní}

Korporátní daně se řadí mezi důchodové, přímé daně. Tato skupina daní patř̌i k nejmladším typům zdanění v daňových systémech. V současné době se zdaňuje zisk firmy, který vychází z účetního výsledku hospodaření a následně je dle daňové legislativy upraven pro zdanění (tzv. daňový základ). Ačkoli se lze v odborné terminologii setkat také s pojmy daň ze zisků korporací, důchodová daň korporací, korporátní daň apod., článek bude používat pojem korporátní daň. V České republice je tato daň známá pod pojmem daň z př́ijmů právnických osob (viz druhá část zákona č. 586/1992 Sb., o daních z př́ijmů, v platném znění). Tato nejednoznačnost souvisí s legislativním ošetřením těchto příjmů u různých druhů společností $\mathrm{v}$ různých zemích, kdy stát uplatňuje odlišnou daňovou politiku vůči těmto subjektům. V některých zemích existuje zvláštní daň pro akciové společnosti a ostatní formy právnických osob jsou zdaňovány jiným způsobem. Například v českém daňovém právu existuje jedna základní sazba daně pro právnické osoby, které jsou vymezeny obchodním zákoníkem (v roce 2011 je stanovena ve výši 19 \%, viz $§ 20$, bod 1 zákona č. 586/1992 Sb., o daních z příjmů, v platném znění). Speciální sazba $5 \%$ platí dle $\S 20$, bod 2 a 3 výše uvedeného zákona pro přesně specifikované subjekty (penzijní fondy, investiční fondy a podílové fondy). Sazba daně $15 \%$ se vztahuje na samostatný základ daně podle $§ 20$ b zákona č. 586/1992 Sb., o daních z př́ijmů, v platném znění.

Korporátní daň osob je v současné ekonomické teorii často diskutována. Existují dva proudy názorů - integralistický a absolutistický. Integralistický př́istup vychází z faktu, že všechny daně v konečné fázi platí jednotlivci, a že měření skutečného ekonomického zisku je velmi složité. Tento přístup kritizuje opodstatnění korporátní daně, protože v konečném důsledku se zisk firem stane osobním důchodem fyzické osoby a podlehne osobní důchodové dani. To znamená, že zisk je zdaněn dvakrát, a to na úrovni podnikatelské jednotky (platí daň ze zisku) a na úrovni samotného poplatníka ve formě daně z příjmů vztahující se na dividendy, různé podíly ze zisku apod. Zastánci integralistického př́stupu se ve svých analýzách zabývají zejména způsoby, jak daň $\mathrm{z}$ firemních zisků zohlednit $\mathrm{v}$ osobní důchodové dani. Je upozorňováno na to, že tato daň negativně působí v souvislosti se zdražováním výroby a zvyšuje tak cenu finálních výrobků. Rovněž je třeba vzít v úvahu problematiku převodu účetního výsledku hospodaření (účetního zisku) na daňový základ, což zvyšuje administrativní zátěž a vede $\mathrm{k}$ distorznosti daní. Nadnárodní společnosti tak mají větší 
možnost manipulace se svým daňovým základem, která je podmíněna i složitostí daňové legislativy v různých zemích a daň tak ztrácí svůj neutrální charakter. Na rozdíl od osobní důchodové daně není prvotním cílem firemní daně zajištovat naplnění principu spravedlnosti, také z tohoto důvodu jsou její sazby obvykle lineární a bývají většinou určeny procentem ze zdanitelného zisku.

Stoupenci absolutistického prrístupu souhlasí s existencí korporátní daně a tvrdí, že zejména velké firmy jsou právní jednotkou s vlastním rozhodováním, mají svoji zdanitelnou kapacitu a ovlivňují ekonomické procesy. Korporátní daň podle nich může být chápána jako kompenzace za limitované ručení vlastníků firmy za své závazky, ovšem to odporuje požadavku neutrality zdanění. V souvislosti s principem prospěchu jako „platba“ za využívání veřejných služeb a infrastruktury na území, kde podnikají. V rámci korporátní daně mohou být rovněž zdaněny zisky, které by případně mohly, at’ už legálně či nelegálně, na úrovni zdanění fyzických osob uniknout.

Široký (2008) poukazuje na rozdílnost propojení osobní důchodové daně a korporátní daně $\mathrm{v}$ jednotlivých zemích, nebot' tvrdí, že pro posouzení parametrů př́ímých daní je důležitý používaný systém integrace korporátní daně do osobní důchodové daně. Rozlišuje tř̌i základní kategorie systémů korporátního zdanění: klasický systém s nulovou integrací (daní se dividenda i zisk), systém zamezující dvojímu zdanění a systém eliminující dvojí zdanění (úplná integrace). Celý systém integrace obou důchodových daní se v praxi neustále vyvíjí a je komplikován i tím, že v mnoha zemích je použito rozdílné pravidlo v prŕípadě tuzemských a zahraničních dividend. Situaci v jednotlivých zemích EU zachycuje Schéma 1.

Schéma 1: Systémy korporátního zdanění v EU (2008)

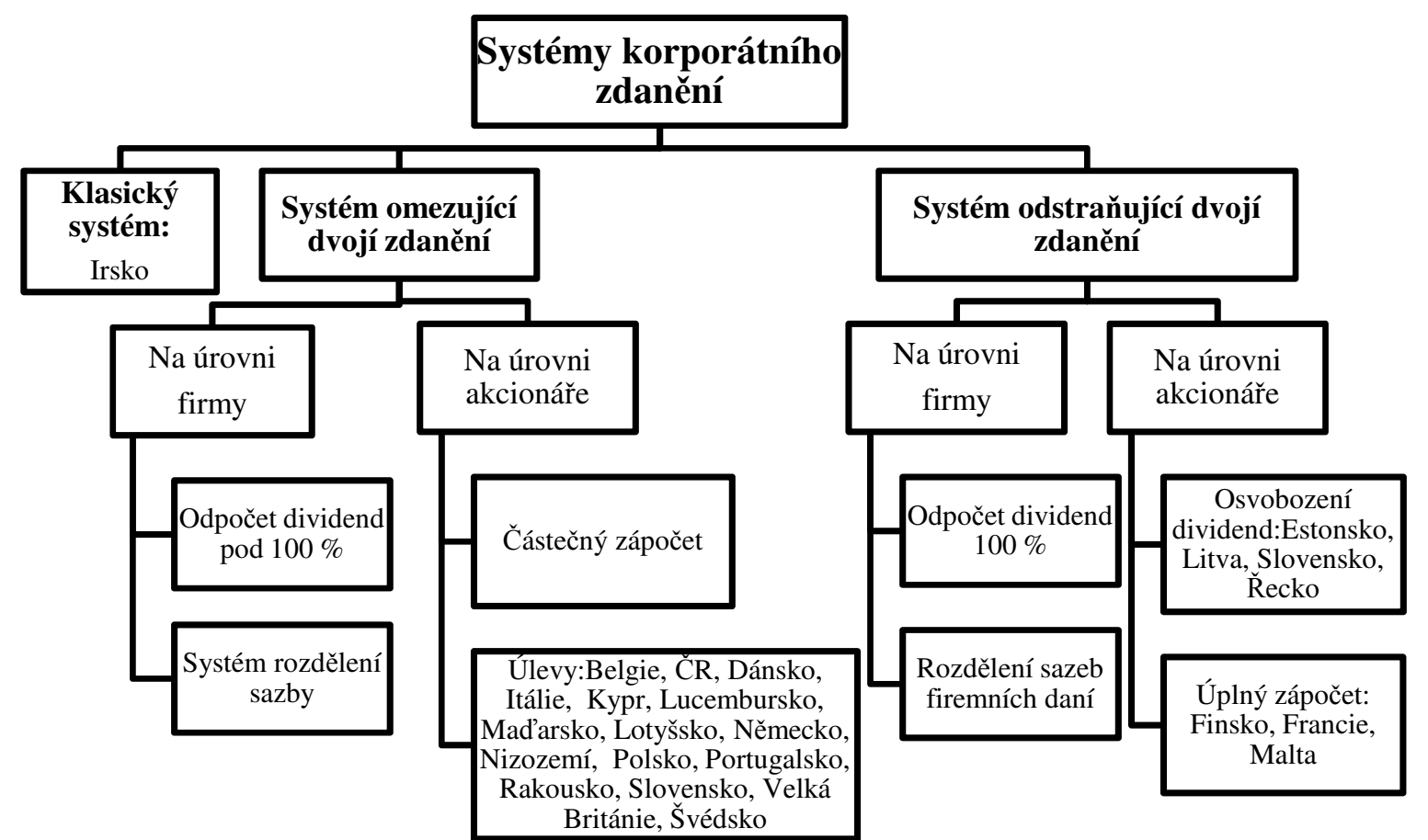

Pramen: Široký (2008), doplněno o data z Taxes in Europe [online databáze] [cit 2010-09-23].

Klasický systém nulové integrace zůstal zachován pouze v Irsku. Další země uplatňují systémy omezující dvojí zdanění, přičemž se zaměřují na úpravy na úrovni akcionáře. Metodu částečného zápočtu využívá Španělsko. Jak je patrné, nejčastěji uplatňovanou metodou 
propojení obou př́ijmových daní je metoda úlev na úrovni akcionáře, která je preferována v šestnácti z 25 zemí Evropské unie (není zde zahrnuto Rumunsko a Bulharsko z důvodu absence dat). Osvobození dividend je uplatňováno ve čtyřech zemích, úplný zápočet daně ve třech zemích.

Korporátní daň z pozice nástroje hospodářské politiky je u příznivců „volné soutěže“ a „,rovných podmínek“ prosazována ve stejné výši pro všechny subjekty. Protekcionisté ale tvrdí, že vhodná úprava korporátní daně může podniky podnítit k většímu vývozu výrobků do zahraničí, k rychlejšímu zavádění nových technologií nebo k podpoře určitých odvětví. Daňové slevy a odpočty mají za cíl podpořit určité investice a prrípadně přilákat zahraniční investory. Mohou mít různou podobu ve formě výjimek, odpočtů a slev ze zdanění.

\section{Přístupy k měření korporátního zatížení}

Se vstupem nových zemí do EU se zostřila debata o výhodách a nevýhodách nízkých daní, a to především u korporátních daní, nebot' právě nové členské země jsou často kritizovány za svou „daňově prŕínivou politiku“, což je dokazováno nižšími sazbami i celkovými výnosy. Otázkou je, na základě kterých sazeb porovnávat korporátní daňové zatížení.

\subsection{Statutární daňové sazby}

Nejjednodušší variantou pro komparaci korporátního zdanění je porovnání statutárních korporátních sazeb. Tyto sazby jsou často používané pro svoji jednoduchost a snadnou dostupnost údajů. Pozornost je však třeba věnovat skutečnosti, že statutární daňové sazby v sobě mohou zahrnovat kromě vlastní tzv. nominální daňové sazby také dočasné či stálé doplňkové sazby či úlevy a navíc ve velké části zemí je korporátní daň vybírána na více úrovních vlád. Jejich konstrukce je tedy v různých zemích odlišná. Možnost objektivního porovnávání korporátního daňového zatížení v různých zemích podle statutárních sazeb daní je také významným způsobem omezena $\mathrm{v}$ důsledku nestejných pravidel pro stanovení výše základu daně z př́ijmů korporací, která vyplývají z daňové legislativy platné v těchto zemích. Statutární daňové sazby tak nemohou plnit úlohu objektivního ukazatele pro účely vzájemného mezinárodního srovnávání. Podrobnosti viz Blechová (2008), Szarowská (2008).

\subsection{Efektivní daňové sazby}

Vhodnějším měřítkem pro porovnání daňového zatížení korporací se jeví efektivní korporátní daňové sazby, což jsou daňové sazby, jejichž velikost ovlivňuje nejen výše statutárních korporátních daňových sazeb, ale i jiné aspekty daňových systémů určující celkovou výši efektivně placených daní. Berou v úvahu daňový základ a také způsob (existuje-li nějaký), pomocí kterého jsou integrovány systémy korporátní daně a osobní daně z příjmů. Vliv daňového systému na čistou návratnost investice závisí na mnoha okolnostech - ziskovosti investice, právním statutu investující firmy, zdrojích financování aj. V případě efektivních sazeb lze nalézt tři základní metody pro jejich stanovení, a to metody zpětného makropohledu, zpětného mikropohledu a dopředného mikropohledu. Jak uvádí Devereux a Griffith (1998), OECD (2000), Nicodéme (2001), Sørensen (2004) či Devereux (2006), rozdíly mezi jednotlivými přístupy jsou dány rozdíly v používaných datech.

\section{Metody zpětného makropohledu}

Metody založené na zpětném makropohledu určují efektivní korporátní daňovou sazbu z agregovaných dat obsažených $\mathrm{v}$ národním účetnictví jednotlivých zemí, která jsou publikovaná národními nebo mezinárodními organizacemi (nap̌r. OECD). Data ze systémů národních účetnictví jsou často využívána při tvorbě politiky EU. Pozitivem je spolehlivost, 
spojitost, vzájemná srovnatelnost a aktuálnost časových řad, které umožňují sledování změn celkového efektivního daňového zatížení a koherentní rámec pro srovnávání daňových výnosů s př́ijmovými toky a ekonomickými agregáty. Blechová (2008) podotýká, že tato metoda a sazby nejsou nejvhodnější pro rozhodování o alokaci investic pro relativně vysoký stupeň agregace dat. Efektivní daňové sazby jsou zde stanovovány jako poměr agregovaných daní z př́ijmů nebo ze zisků placených korporacemi k hodnotě různě agregovaného daňového základu.

\section{Metody zpětného mikropohledu}

Metody zpětného mikropohledu využívají k výpočtu efektivního korporátního daňového zatížení finanční výkazy jednotlivých společností, přičemž existují tř̀i způsoby stanovení těchto efektivních korporátních daňových sazeb, které se počítají jako poměr mezi daněmi odvedenými z korporátních př́ijmů nebo zisků a daňovým základem, kterým může být:

- celkový výsledek hospodaření před zdaněním (tzn. výsledek hospodaření $\mathrm{z}$ běžné činnosti před zdaněním + mimořádné výnosy - mimořádné náklady),

- celkové provozní výnosy neboli čistý obrat,

- hrubý provozní výsledek hospodaření (tzn. celkové provozní výnosy - provozní náklady - jiné provozní poplatky a daně - osobní náklady).

Varianta používající celkový výsledek hospodaření před zdaněním je nejvhodnější, pokud chceme srovnávat efektivní korporátní daňové sazby se statutárními sazbami. Vzájemné srovnávání takto vypočtených efektivních daňových sazeb mezi jednotlivými zeměmi ovšem může být problematické s ohledem na rozdílnou účetní legislativou jednotlivých zemí, nebot' ta významně ovlivňuje vymezení daňového základu a v důsledku i výslednou efektivní sazbu. Při výpočtu s čistým obratem je nutné respektovat při posuzování výsledků následující skutečnost. Čistý obrat je použit ve jmenovateli, k němu jsou poměřovány odvedené daně, a to může mít zkreslující účinek, jelikož při tomto výpočtu schází údaje o nákladech. Nízká hodnota takto vypočtené efektivní daňové sazby tedy nemusí znamenat nízkou míru skutečného daňového zatížení, ale může být důsledkem vysokých nákladů ve společnosti, které musí být pokryty provozními výnosy, takže zdanitelný výsledek hospodaření je nízký a proto nízké jsou i celkově odvedené daně, přestože statutární daňová sazba může být vysoká.

Použití hrubého provozního výsledku hospodaření ve jmenovateli zlomku pro stanovení efektivní korporátní daňové sazby využívá výsledek hospodaření před započtením odpisů. To je důležité, pokud chceme získat jmenovatel, který se vymezením příliš neliší v jednotlivých zemích. Pravidla pro odepisování se v jednotlivých zemích liší nejen povolenou rychlostí odepisování a rovnoměrností, ale také způsobem určování ceny odepisovaných aktiv, tzn., zda se vychází z historických nebo tržních cen. Volba hrubého provozního výsledku hospodaření jako základu pro výpočet efektivních daňových sazeb tak umožňuje eliminovat problém rozdílných pravidel pro odepisování používaných v různých státech. Hrubý provozní hospodářský výsledek je vzájemně srovnatelnější mezi jednotlivými státy než výsledek hospodaření z běžné činnosti.

Efektivní korporátní daňové sazby stanovené dle této varianty mohou být počítány nejen podle jednotlivých zemí, ale také v podrobnějším členění podle různých odvětví, velikostních skupin podniků nebo let. Jejich průměrné hodnoty za určitou zemi podle odvětví a velikostních skupin podniků $\mathrm{v}$ určitém období se počítají jako podíl součtu podobných položek za dané období. Data potřebná pro výpočet průměrné hodnoty efektivní korporátní sazby daně v rámci EU podle této metodologie lze získat z databáze $\mathrm{BACH}$ (Bank for the 
Accounts of Companies Harmonised), která je vytvářena a publikována Evropskou komisí. Tato databáze obsahuje soubor finančních výkazů individuálních společností (nikoliv konsolidovaných nebo skupinových výkazů) ve struktuře stanovené čtvrtou směrnicí Rady EU (76/660/EEC) upravující právní stav obchodních společností v Evropském společenství. Databáze obsahuje finanční struktury nefinančních společností agregované podle různých odvětví a velikostních skupin podniků a nabízí údaje členěné podle šesti hlavních odvětví energie a vodní hospodářství, průmyslová výroba, stavební výroba, obchod, doprava a spoje, jiné služby. Tyto údaje mají výhodu v tom, že ukazují skutečné daňové zatížení konkrétních společností, avšak mohly by být zavádějící v případě použití pro stanovení a vzájemné porovnání efektivního domácího korporátního zatížení mezi jednotlivými státy. Důvodem je, že př́stupy založené na ex-post datech specifických pro společnosti neberou v úvahu interakci mezi osobním a korporátním zdaněním, která je důležitá v př́ípadě, že marginální investor je domácím investorem. Selhávají také v případě, že bychom je chtěli použít pro hodnocení pobídek pro dodatečné investice nebo pro korektní zjišt'ování příjmů pocházejících z cizích zdrojů na základě údajů z individuálních nebo konsolidovaných účetních výkazů společností. Navíc tato data mají někdy tendenci vykazovat významné roční výkyvy závisející na hospodářském cyklu. Z toho důvodu ukazatele korporátní daňového zatížení využívající zisk vykazovaný metodou zpětného pohledu nejsou přesné, pokud se jedná o možnost posuzování vlivu daní na investiční pobídky. Umožňují však určovat skutečné efektivní daňové zatížení podle velikosti firem nebo podle odvětví.

\section{Metody dopředného mikropohledu}

Ukazatele korporátního daňového zatížení vypočtené podle této metody jsou všeobecně používány pro analýzu vlivu daní na investiční rozhodování korporací. Umožňují mezinárodní srovnávání a jsou zkonstruovány tak, aby mohly sledovat účinky zdaňování na pobídky pro investování, které jsou rozdílné v jednotlivých národních daňových zákonech. Mezi základní metody výpočtu efektivního korporátního zatížení s využitím dopředného mikropohledu patří metoda Kinga a Fullertona (1984) a metoda OECD (1991). Následně Devereux a Griffith (1998) tyto metody dopracovali a rozšíríili. Všechny tři metody vycházejí z předpokladu, že všechny trhy, zejména trh výrobních prostředků, jsou konkurenční a produkční funkce má obvyklé vlastnosti. V takové situaci rozhodování o tom, zda a kde investovat, je ovlivněno pouze mírou zdanění kapitálu, nikoliv daněmi nebo příspěvky odvozenými z jiných faktorů jako jsou např. mzdy, energie apod. Pokud nebudeme brát v úvahu vliv daní, pak investor, který vložil peníze do určitého investičního projektu, získá míru návratnosti rovnající se míře návratnosti samotného projektu. $\mathrm{V}$ případě zohlednění daně pak dosažená míra návratnosti tohoto projektu bude nižší. Jejich rozdíl je označován jako daňový klín. Jeho velikost závisí, mezi jiným, na systému korporátního zdanění, na vzájemném účinku zdanění a inflace, na daňovém posuzování odpisů, zásob a různých právně přípustných forem zisku a na řadě jiných prvků souvisejících s definicí daňového základu. Efektivní daňová sazba je proto závislá i na odvětví, ve kterém je investováno, na druhu pořizovaných aktiv, na způsobu financování investice a na identitě investora, který poskytuje finance.

Devereux a Griffith (1998) rozlišují dvě různé sazby daňového zatížení korporací:

- efektivní marginální daňovou sazbu (EMTR - Effective Marginal Tax Rate),

- efektivní průměrnou daňovou sazbu (EATR - Effective Average Tax Rate).

Efektivní marginální daňová sazba EMTR je vypočtena pro mezní, tedy přírůstkové investice v určité zemi, realizované společností, která je rezidentní bud' v této zemi (domácí investice) nebo v některé jiné zemi (zahraniční investice). Devereux a Griffith (1998) marginální investicí rozumí takovou investici, u které očekávaná míra návratnosti investice před 
zdaněním $p^{\circ}$ je právě postačující $\mathrm{k}$ přesvědčení investora, že investice do realizovaného projektu „stojí za to“, tj. kdy se minimálně rovná hodnotě skutečné úrokové míry $r$ (skutečná zde znamená reálnou, tzn. po zohlednění inflace). V tomto př́ípadě se bude čistá současná hodnota investice před zdaněním $R^{\circ}$ (označovaná také jako čistá současná hodnota ekonomické renty generované investicí před zdaněním)rovnat nule, přičemž $R^{\circ} j e$ definovaná jako $R^{\circ}=\left(p^{\circ}-r\right) /(1+r)$. Čistá současná hodnota ekonomické renty po zdanění $R$ je v tomto případě také rovna nule. EMTR je pak počítána jako poměr rozdílu míry návratnosti marginální investice před zdaněním $p^{\circ}$ a míry návratnosti této investice pro investující osobu (např. akcionáře) po zdanění $s$ k míře návratnosti marginální investice před zdaněním $p^{\circ}$ :

$$
\text { EMTR }=\frac{p^{\circ}-s}{p^{\circ}}
$$

Pokud bereme v úvahu zdanění a určíme minimální míru návratnosti investice pro investora po zdanění $s$ ve výši úroků, které by investor obdržel při jiném využití investovaných finančních prostředků, je možné na základě daňového předpisu vypočítat míru návratnosti této hypotetické investice před zdaněním $p$, která by měla být požadována, aby bylo dosaženo požadované míry návratnosti investice po zdanění $s$. Čím bude tvrdší daňový systém a čím méně umožňuje úlev, odpočtů a výjimek, tím větší bude pro danou požadovanou hodnotu $s$ požadovaná míra návratnosti investice před zdaněním $p$, označována také jako „náklady na kapitál“. Tím bude rovněž menší pravděpodobnost, že investiční projekt bude realizován. Porovnáme-li pomocí popsaného modelu vliv daní na očekávanou návratnost zamýšlené investice, pokud by byla realizována $\mathrm{v}$ různých zemích, dospějeme $\mathrm{k}$ závěru, že země $\mathrm{s}$ většími náklady na kapitál nebo s větší hodnotou EMTR budou z hlediska investování méně atraktivní.

V případě různých forem investic, které jsou ziskovější než marginální investice (když $p>r$ a když firma očekává kladnou ekonomickou rentu po zdanění $R$ ), metoda Devereuxe a Griffitha (1998) počítá efektivní korporátní daňové zatížení pomocí ukazatele EATR. Obvyklý postup pro stanovení tohoto ukazatele spočívá v proporcionální redukci ekonomické renty generované danou investicí v důsledku zdanění, tzn. EATR $=\left(R^{\circ}-R\right) / R^{\circ}$. Nedostatkem takového postupu však je, že neumožňuje definovat hodnotu EATR u investičních projektů, které se jeví jako marginální při absenci zdanění, tzn., u některých je $R^{\circ}=0$. Proto Devereux a Griffith (1998) představili mírně odlišný postup stanovení EATR spočívající v tom, že rozdíl mezi $R^{\circ}$ a $R$ poměřují čistou současnou hodnotou návratnosti investice před jejím zdaněním korporátní daní, danou výrazem $p /(1+r)$. Současně zohledňují vliv marginální osobní efektivní daňové sazby z definované Kingem a Fullertonem (1984) z kapitálových výnosů plynoucích individuálním investorům (akcionářům) z této investice, která snižuje hodnotu $R$ :

$$
E A T R=\frac{R^{\circ}-(1-z) R}{p /(1+r)}
$$

Vztah mezi mezní a průměrnou efektivní sazbou lze získat po úpravě:

$$
E A T R=\frac{p^{\circ}}{p} E M T R+\frac{p-p^{\circ}}{p} \tau
$$

kde $\tau$ je statutární korporátní daňová sazba.

Opodstatněnost takového přístupu je dána skutečností, že společnost, která se rozhoduje o realizaci určité investice, musí často vybírat mezi dvěma či více vzájemně se vylučujícími lokalitami nebo typy investic. Příkladem jsou nadnárodní společnosti, které se musí 
rozhodovat o umístění nové provozní jednotky v některém státě nebo o volbě investičního projektu při limitovaných finančních prostředcích. V tomto případě je výsledek výběru závislý na míře zdanění těchto marginálních investic, kterou vyjadřuje právě hodnota EATR. Devereux a Griffith (1998) poukazují na to, že v př́ípadě absence osobních daní se takto určená hodnota EATR pohybuje od hodnoty rovnající se EMTR u marginálních investic, u nichž je $p=p^{\circ}$ až po tzv. „upravenou statutární korporátní daňovou sazbu“, která se rovná hodnotě $1-\gamma(1-\tau)$ u vysoce ziskové investice, kde parametr $\gamma$ označuje čistý výnos připadající individuálnímu investorovi (akcionáři) v důsledku navýšení dividend o jednu jednotku a definují ho takto:

$$
\gamma=\frac{\left(1-m_{d}\right)(1-c)}{(1-z)(1-s)}, \text { prìčemž platí, že }(1-c)=\left(1-\tau_{D}\right) /(1-\tau)
$$

kde:

$\mathrm{m}_{\mathrm{d}} \quad$ - marginální osobní sazba daně z příjmů investora (akcionáře) týkající se jeho dividendových příjmů generovaných investicí,

c - sazba čisté daně z výnosů cenných papírů uvalené na dividendy poskytnuté firmou investorovi (akcionáři),

s - je poměr daňového dobropisu náležejícího investorovi (akcionáři) u přijatých dividend $\mathrm{k}$ celkovému objemu těchto přijatých dividend,

$\tau$ - korporátní daňová sazba na nerozdělený zisk,

$\tau_{\mathrm{D}}$ - korporátní daňová sazba na rozdělený zisk.

V případě, že nerozdělený zisk generovaný investicí je zdaňován stejnou korporátní sazbou jako zisk rozdělený investorům (akcionářùm) ve formě dividend, tzn. že $\tau=\tau_{D}$, pak parametr $c=0$. Pokud při zdaňování dividend přijatých investorem (akcionářem) osobní daní z kapitálových př́jmů je mu současně plně dobropisována daň odvedená korporací z těchto dividend, tzn., když $s=\tau_{D}=\tau$, pak $\gamma=\left(1-m_{d}\right) /(1-\tau)(1-z)$. Tento postup určování EATR je zcela obecný tím, že uvažuje s investicí umožňující dosažení libovolné úrovně ziskovosti a zahrnuje rovněž hodnotu EMTR. Tato metoda se pro svou komplexnost jeví jako nejpřesnější pro porovnávání skutečného korporátního daňového zatîžení.

\section{Sazby používané k porovnání výše daňového zatížení}

Všechny výše uvedené metody mají své výhody i nevýhody. Například přístupy založené na zpětném pohledu jsou schopny zjišstovat rozdíly $\mathrm{v}$ mirre celkového zdanění na národní úrovni, zatímco přístupy založené na dopředném pohledu zase mohou zjišt'ovat rozdíly v daňovém zatížení různých typů investic při různých způsobech jejich financování. Metody založené na zpětném pohledu využívají skutečná data, metody založené na dopředném pohledu využívají sazby teoreticky vypočtené podle charakteristik daňových systémů. Proto metody s př́stupem na bázi dopředného pohledu nepočítají skutečné efektivní daňové sazby, ale sazby implicitní. Metody se zpětným pohledem nemohou zajistit izolování národního daňového systému od vlivů jiných národních daňových systémů na rozdíl od metod využívajících prrístup s dopředným pohledem. Př́istupy k porovnávání výše korporátního daňového zatížení se v dostupných empirických studiích (z období 1985-2008) velmi liší a nabízejí použití rozdílných sazeb. Souhrn používaných sazeb prezentují údaje v Tabulce 1. Zkoumané studie jsou seřazeny chronologicky a všechny se zabývají vlivem výše korporátního daňového zatížení na umístění kapitálu. 
Tabulka 1: Sazby použivané k porovnání korporátního daňového zatížení

\begin{tabular}{|c|c|}
\hline Sazba & Studie \\
\hline $\begin{array}{l}\text { Průměrná } \\
\text { daňová sazba }\end{array}$ & $\begin{array}{l}\text { Hartman (1985), Boskin a Gale (1987), Young (1988), Murthy (1989), } \\
\text { Hines a Rice (1994), Swenson (1994), Kemsley (1998), Benassy-Quere et } \\
\text { al. (2000), Grubert a Mutti (2000), Altshuler et al. (2001), Buettner (2001), } \\
\text { Devereux a Sørensen (2005) }\end{array}$ \\
\hline EMTR & $\begin{array}{l}\text { Slemrod (1990), Devereux a Freeman (1991), Cummins a Hubbard (1995), } \\
\text { Benassy Quere et al. (2000), Buettner (2001) }\end{array}$ \\
\hline EATR & $\begin{array}{l}\text { Mendoza et al. (1994), Benassy-Quere et al. (2000), Devereux a Griffith } \\
\text { (2003) }\end{array}$ \\
\hline $\begin{array}{l}\text { Jiná daňová } \\
\text { sazba }\end{array}$ & Wheeler a Mody (1992), Hines (1999), Billington (1999), Young (1999) \\
\hline
\end{tabular}

Zdroj: uvedené studie Devereux a Griffith (2003), Devereux (2006)

Ve zkoumaných studiích byla nejčastěji používanou sazbou ke komparaci korporátního daňového zatížení průměrná daňová sazba, tedy hodnota efektivní korporátní sazby stanovená metodou zpětného mikropohledu, založená na skutečně zaplacených daních. Autoři ji používají zejména pro jednoduchost a dostupnost požadovaných dat. Tímto způsobem např. zkoumají vliv změn daňového zatížení v čase na hodnotu přímých zahraničních investic. Průměrná daňová sazba bývá také často použita v případě zkoumání vlivu rozdílné výše zdanění na alokaci kapitálu nadnárodních amerických společností, a to podle umístění nebo odvětví, napřr. Hines a Rice (1994), Swenson (1994), Grubert a Mutti (2000).

Sazby založené na metodě dopředného mikropohledu jsou počítány pro hypotetickou investici, přičemž jejich výpočet vychází z aktuální legislativy pro daňový základ a daňové sazby. Teoreticky mohou být kalkulovány pro jakýkoli projekt. V praxi jsou tyto př́stupy využívány ve dvou variantách. Někteří autoři preferují komparaci na základě výpočtu efektivní marginální daňové sazby EMTR nebo nákladů kapitálu (viz Slemrod (1990), Devereux a Freeman (1991), Cummins a Hubbard (1995)), jiní používají efektivní průměrnou daňovou sazbu EATR, např. Devereux a Griffith (2003). V př́ípadě výpočtu efektivních sazeb založených na dopředném mikropohledu je možné postihnout vliv kombinace několika charakteristik ovlivňujících efektivní zdanění (např̀. absenci nebo změnu některých charakteristik, které vymezují daňový základ), ale z praktických důvodů není možné brát v úvahu všechny, protože by si to vyžádalo neúměrné rozšíření matematického modelu.

Někteří autoři se snaží eliminovat slabiny jednotlivých sazeb a využívají k posuzování výše korporátního zatížení více sazeb. Např. Benassy-Quere et al. (2000) pracují s EMTR i EATR, Buettner (2001) posuzuje umístění kapitálu pomocí EMTR a efektivní korporátní sazby stanovené metodou zpětného mikropohledu.

Existují také studie, které používají jiné než výše uvedené daňové sazby, v těchto případech je nejčastěji využívanou statutární korporátní daňová sazba. Dủvodem je zejména jednoduchost metody a snadná dostupnost dat.

Rozdíl v použitých metodách a sazbách je také v tom, zda daná metoda zkoumající zdanění je orientovaná na národnost daňového systému nebo na národnost korporace. Metody dopředného mikropohledu se upřednostňují při analýzách národnost daňových systémů. Předmětem zájmu je zdaňování tuzemských společností v podmínkách domácího daňového systému. Přri zkoumání činnosti a dopadů zdanění z operací realizovaných v zahraničí, je slabinou nedostatek informací o podílu a významu těchto operací pro celkový obrat 
společnosti. U zpětného makropohledu je stanovení výsledného korporátního zatížení komplikovanější a závisí na způsobu, jakým jsou data shromažd'ována.

\section{Závěr}

S pokračující globalizací se kapitál stává stále mobilnějším mezi zeměmi a multinárodní společnosti se rozhodují, kde umístit svá aktiva. Daňové prostředí a velikost korporátního daňového zatížení je významným faktorem při rozhodování o alokaci investic. V případě komparace výše korporátního daňového zatížení je však možné použít několik metod a sazeb. Nejjednodušší variantou je porovnání statutárních korporátních sazeb daní z příjmů, ty však nezohledňují odlišnou konstrukci daňového základu v jednotlivých zemích, dočasné či stálé doplňkové sazby či úlevy. Statutární sazby tak nejsou vhodnými ukazateli pro porovnávání skutečného daňového zatížení. Proto se pro tyto účely častěji využívají efektivní korporátní sazby daně. Srovnání statutárních a efektivních daňových sazeb dává představu o daňových pobídkách poskytovaných úřady $\mathrm{v}$ jednotlivých zemích. $\mathrm{Z}$ porovnání a rozdílů $\mathrm{v}$ efektivních korporátních daňových sazbách mezi jednotlivými zeměmi je možné usuzovat, zda zde existují podstatně odlišné daňové přístupy ke společnostem, které mají shodné charakteristiky, ale jsou dislokovány $\mathrm{v}$ různých zemích. Tyto údaje mohou indikovat, zda se za velkými rozptyly statutárních daňových sazeb neskrývají pouze malé rozdíly v efektivním zdanění, jelikož země s vysokými statutárními daňovými sazbami mohou zmenšovat velikost daňového základu nebo změkčovat daňovou vymahatelnost systémy úlev a výjimek.

V případě efektivních sazeb lze nalézt tři základní metody, a to metodu zpětného makropohledu, zpětného mikropohledu a dopředného mikropohledu. Rozdíly mezi jednotlivými přístupy jsou dány rozdíly v používaných datech a různém stupni agregace dat. Makro přístup vypočítává efektivní daňové sazby z agregovaných makroekonomických dat obsažených v národním účetnictví jednotlivých zemí. Mikro přistupy korporátní efektivní sazby počítají z finančních výkazů jednotlivých společností obsahujících bud' empirická, nebo teoretická data. Přístupy se zpětným mikropohledem využívají k odhadu velikosti korporátního daňového zatížení společností ex-post data týkající se reálného výsledků společností, zatímco přístupy $\mathrm{s}$ dopředným mikropohledem využívají statutární charakteristiky daňového systému $\mathrm{k}$ určení daňových aspektů týkajících se budoucích podnikatelských rozhodnutí společností. Na základě výsledků shromážděných empirických studií lze konstatovat, že při rozhodování o umístění kapitálu jsou nejčastěji používány průměrné efektivní korporátní sazby stanovená metodou zpětného mikropohledu, efektivní marginální daňové sazby EMTR nebo průměrné efektivní daňové sazby EATR. Každá z nich má své výhody i nevýhody, proto jejich volba závisí na charakteru investice, její velikosti, odvětví investice a dalších záměrech. Průměrná efektivní daňová sazba EATR se však pro svou komplexnost jeví jako nejpřesnější pro porovnávání korporátního daňového zatížení.

\section{Literatura:}

[1] ALTSHULER, R. et al. Has US investment abroad become more sensitive to tax rates? In HINES, J. R. (ed.) International Taxation and Multinational Activity. Chicago : University of Chicago Press, 2001. ISBN 9780226341736.

[2] BENASSY-QUERE, A., FONTAGNE, L., LAHRECHE-REVIL, A. Foreign Direct Investment and the Prospects for Tax Co-Ordination in Europe [online]. CEPII Research Center, $2000 \quad$ [cit. 2008-03-10]. Dostupný z: http://www.cepii.fr/anglaisgraph/workpap /pdf/2000/wp00-06.pdf. 
[3] BILLINGTON, N. The location of foreing direct investment: An empirical analysis. Applied Economics, 1999, vol. 31, 65-76. ISSN 0003-6846.

[4] BLECHOVÁ, B. Charakteristika přístupů používaných v EU pro hodnocení efektivního daňového zatížení př́íjmů korporací [CD]. In Teoretické a praktické aspekty veřejných financí. Praha : VŠE, 2008. ISBN 978-80-245-1378-2.

[5] BOSKIN, M. J., GALE, W. G. New results on the effects of tax policy on the international location of investment. In M. FELDSTEIN (ed.) The Effects of Taxation on Capital Accumulation. Chicago : University of Chicago Press, 1987. ISBN 0226240886.

[6] BUETTNER, T. Local business taxation and competition for capital: the choice of the tax rate. Regional Science and Urban Economics, 2001, vol. 31, 215-245. ISSN 0166-0462.

[7] CUMMINS, J. G., HUBBARD, R. G. The tax sensitivity of foreing direct investment: Evidence from firm level panel data. In M. FELDSTEIN (ed.) The Effects of Taxation on Multinational Corpotrations. Chicago : University of Chicago Press, 1995, 123-147. ISBN 0-226-24095-9.

[8] DEVEREUX, M. P. Developments in the Taxation of Corporate Profit in the OECD since 1965: Rates, Bases and Revenue [online]. University of Warwick, IFS and CEPR, 2006. [cit. 2010-09-02]. Dostupný z: www.aei.org/docLib/20060602_devereux.pdf.

[9] DEVEREUX, M. P., FREEMAN, H. A general neutral profits tax. Fiscal Studies, 1991, vol. 12, 1-15. ISSN 1475-5890.

[10] DEVEREUX, M. P., GRIFFITH, R. The Impact of Corporate Taxation on the Location of Capital [online]. Economic Analysis and Policy. 2003, vol. 33(2), 275-292 [cit. 200809-02]. Dostupný z: http://www.eap-journal.com/download.php?file=466.

[11] DEVEREUX, M. P., GRIFFITH, R. The taxation of discrete investment choices [online]. Institute for Fiscal Studies, Working Paper Series No. W98/16, 1998 [cit. 2010-09-02]. Dostupný z www: http://ideas.repec.org/p/ifs/ifsewp/98-16.html.

[12] DEVEREUX, M. P., SØRENSEN, P. B. The Corporate Income Tax: International Trends and Options for Fundamental Reform [online]. 2005 [cit. 2008-02-10]. Dostupný z http://www.unicatt.it/Dottorati/Defap/Allegati/Paper_Devereux.pdf.

[13] Effective Tax Rates: A Critical Survey. Paris : OECD, 2000. ISBN 978-9264195455.

[14] GRUBERT, H. MUTTI, J. Do taxes influence where US corporations invest? National Tax Journal, 2000, vol. 37, 475-488. ISSN 0028-0283.

[15] HARTMAN, D. Tax policy and foreign direct investment. Journal of Public Economics, 1985, 26, 107-121. ISSN 0047-2727.

[16] HINES, J. Lessons from Behavioral Responses to International Taxation. National Tax Journal, 1999, vol. 52, 269-304. ISSN 0028-0283.

[17] HINES, J. R., RICE, E. Fiscal paradise: Foreing Tax Haven and American Business. Quarterly Journal of Economics, 1994, vol. 109, 149-182. ISSN 0033-5533.

[18] KEMSLEY, D. The efects of taxes on production location. Journal of Accounting Research, 1998, vol. 36, 321-341. ISSN 0021-8456.

[19] KING, M., FULLERTON, D. The taxation of income from capital. Chicago : The University of Chicago Press, 1984, 368 s. ISBN 0-226-43630-6.

[20] MENDOZA, E. G., RAZIN, A., TESAR, L. L. Effective Tax Rates in Macroeconomics: Cross-country Estimates of Tax Rates on Factor Income and Consumption [online]. Cambridge, 1994 [cit. 2009-06-03]. Dostupný z http://www.nber.org/papers/w4864.pdf. 
[21] MURTHY, N. R. V. The effects of taxes and rate of return of foreing direct investment in the United States: Some econometric comments. National Tax Journal, 1989, vol. 42, 205-207. ISSN 0028-0283.

[22] NICODÈME, G. Computing Effective Corporate Tax Rates: Comparison and Results [online]. MPRA Paper No. 3808, 2001 [cit. 2010-06-02]. Dostupný z http://mpra.ub.uni-muenchen.de/3808/.

[23] SLEMROD, J. Tax effects on Foreing Direct Investment in the United States: Evidence from a cross-country comparison. In RAZIN, A., SLEMROD, H. J. (eds.) Taxation in the Global Economy. Chicago : University of Chicago Press, 1990. ISBN 0226705927.

[24] SØRENSEN, P. B. Measuring the tax burden on capital and labor. Cambridge : MIT Press, 2004, 364 s. ISBN 9780262195034.

[25] Stanovisko Evropského hospodářského a sociálního výboru $k$ Vytvoření společného konsolidovaného základu pro dan̆ z př́jmu právnických osob v EU - ECO/165 [online]. [cit. 2009-06-03]. Dostupný z http://www.esc.eu.int.

[26] SWENSON, D. L. The impact of US tax reform on foreing direct investment in the United States. Journal of Public Economics, 1994, 54, 243-266. ISSN 0047-2727.

[27] SZAROWSKÁ, I. Praktické aspekty daňové konkurence v oblasti daně z př́immů právnických osob v Evropské unii. Acta Academica Karviniensia, 2008, č. 2, s. 202215. ISSN 1212 - 415X.

[28] ŠIROKÝ, J. a kol. Daňové teorie s praktickou aplikací. 2. vyd. Praha : C. H. Beck, 2008, 301 s. ISBN 978-80-7400-005-8.

[29] Taxes in Europe [database online]. Brussels : European Commission, 2009 [cit. 200908-15]. Dostupné z

http://ec.europa.eu/taxation_customs/taxation/gen_info/info_docs/tax_inventory/index_ en.htm>.

[30] Taxing Profits in a Global Economy. Paris : OECD Publishing, 1991, 470 s. ISBN 9789264135963.

[31] WHEELER, D., MODY, A. International investment location decision. Journal of International Economics, 1992, vol. 33, 57-76. ISSN 0022-1996.

[32] YOUNG, G. The influence of foreing factor prices and international taxation on fixed investment in the UK. Oxford Economic Paper, 1999, vol. 51, 355-373. ISSN 00307653.

[33] YOUNG, K. H. The effects of taxes and rate of return of foreing direct investment in the United States. National Tax Journal, 1988, vol. 41, s. 109-121. ISSN 0028-0283.

[34] Zákona č. 586/1992 Sb., o daních z př́íjmů, v platném znění.

\section{Klasifikace JEL: F2, H2}

Ing. Irena Szarowská, Ph.D.

Odborný asistent Katedra financí

Obchodně podnikatelská fakulta v Karviné,

Slezská univerzita,

Univerzitní nám. 1934/3, 73340 Karviná

Tel: +420 596398215

szarowska@opf.slu.cz 